\title{
Tumour suppressor menin is essential for development of the pancreatic endocrine cells
}

\author{
Sandra Fontanière ${ }^{1,2}$, Bertrand Duvillié ${ }^{3}$, Raphaël Scharfmann ${ }^{3}$, Christine Carreira $^{1}$, \\ Zhao-Qi Wang ${ }^{2,4,5}$ and Chang-Xian Zhang'
}

${ }^{1}$ CNRS UMR2501, Laboratoire Génétique Moléculaire, Signalisation et Cancer, Université Claude Bernard Lyon, Lyon F-69008, France

${ }^{2}$ International Agency for Research on Cancer, 69008 Lyon, France

${ }^{3}$ INSERM U845, Faculté de Médecine, Centre de Recherche Croissance et Signalisation, Université Paris Descartes, Hôpital Necker, 75015 Paris, France

${ }^{4}$ Leibniz Institute for Age Research, Fritz Lipmann Institute (FLI), 07745 Jena, Germany

${ }^{5}$ Faculty of Biology and Pharmacy, Friedlich-Schiller-University, 07743 Jena, Germany

(Correspondence should be addressed to C-X Zhang at Laboratoire Génétique Moléculaire, Signalisation et Cancer, CNRS, UMR5201, Faculté de Médecine, Université Claude Bernard Lyon 1, 8 Avenue Rockefeller, 69373 Lyon Cedex 08, France; Email: zhang@sante.univ-lyon1.fr)

\begin{abstract}
Mutations of the multiple endocrine neoplasia type 1 (MEN1) gene predispose patients to MEN1 that affects mainly endocrine tissues, suggesting important physiological functions of the gene in adult endocrine cells. Homozygous disruption of Men 1 in mice causes embryonic lethality, whereas the eventual involvement of the gene in embryonic development of the endocrine cells remains unknown. Here, we show that homozygous Men 1 knockout mice demonstrate a reduced number of glucagon-positive cells in the E12.5 pancreatic bud associated with apoptosis, whereas the exocrine pancreas development in these mice is not affected. Our data suggest that menin is involved in the survival of the early pancreatic endocrine cells during the first
\end{abstract}

developmental transition. Furthermore, chimerism assay revealed that menin has an autonomous and specific effect on the development of islet cells. In addition, using pancreatic bud culture mimicking the differentiation of $\alpha$ - and $\beta$-cells during the second transition, we show that loss of menin leads to the failure of endocrine cell development, altered pancreatic structure and a markedly decreased number of cells expressing neurogenin 3 , indicating that menin is also required at this stage of the endocrine pancreas development. Taken together, our results suggest that menin plays an indispensable role in the development of the pancreatic endocrine cells.

Journal of Endocrinology (2008) 199, 287-298

\section{Introduction}

Mutations of the multiple endocrine neoplasia type 1 (MEN1) gene are found in the majority of patients with MEN1, predisposing them to the occurrence of multiple endocrine tumours of the parathyroids, endocrine pancreas and anterior pituitary, as well as, though less frequently, of foregut carcinoids, adrenal cortical tumours and follicular thyroid tumours (Online Mendelian Inheritance in Man no. 131100). While hyperparathyroidism is the most common clinical manifestation of the disease, pancreatic islet tumours, including those of $\alpha-, \beta$ - and pancreatic polypeptide (PP) cells, occur in $30-80 \%$ of MEN1 patients and account for the major cause of death in MEN1 patients due to malignancy (Thakker 1998). The loss of heterozygosity observed in MEN1 tumours (Larsson et al. 1988) supports the hypothesis that the MEN1 gene acts as a tumour suppressor in affected cells.

The protein product of the MEN1 gene, menin, has been shown to interact with a substantial number of well-known transcriptional factors and co-factors, including JUND
(Agarwal et al. 1999), SMAD1, 3 and 5 (Kaji et al. 2001, Sowa et al. 2004), RELA, NFKB2 and NFKB1 of NFKB (Heppner et al. 2001), SIN3A (Kim et al. 2003), MLL1 and 2 (Hughes et al. 2004, Yokoyama et al. 2004, Milne et al. 2005), suggesting that menin is involved in transcriptional regulation of gene expression. Indeed, several genes have been identified as being regulated by menin, such as telomerase (Lin \& Elledge 2003) and cyclin-dependent kinase inhibitors CDKN2C and CDKN1B (Karnik et al. 2007), as well as several hormones including insulin (Sayo et al. 2002), prolactin (Namihira et al. 2002) and parathyroid hormone (Sowa et al. 2004). However, little is known about the in vivo physiological function of menin, and the in vivo importance of the above-mentioned interactions between menin and its protein partners, especially in endocrine cells that are affected in MEN1 disease. It should be noted that Kaji et al. (2001) has shown that menin is required for TGFB1-induced ex vivo growth inhibition of anterior pituitary tumour cells and a similar observation has been made by Sowa et al. (2004) in primary parathyroid cells. By disrupting Men 1 in mice, we have previously shown that menin was 
required for the development of several organs and tissues, such as neural tube and liver (Bertolino et al. 2003a). Consequently this elicits the question about the possible involvement of menin in the development of the pancreatic endocrine cells. Intriguingly, $\beta$-cell specific Men 1 mutant mice showed normal islet structures at an early age (Bertolino et al. 2003c, Crabtree et al. 2003, Biondi et al. 2004). However, one can hardly exclude the possibility that this may be due to partial Cre-mediated gene disruptions among targeted cells during the embryonic stage. Alternatively, menin may play its role before Rip-Cre recombinase (insulin) expression, similar to the genes whose function in the pancreas development is needed only during a narrow period, as in the case of $\beta$-catenin (Heiser et al. 2006).

Substantial advances in the study of development of the pancreatic endocrine cells have been achieved in recent years. The current available data support the notion that sequential activation or repression (Edlund 2002, Wilson et al. 2003) of transcriptional factors and co-factors may play a central role in the control of pancreas development. Indeed, the endodermal region committed to pancreas development first expresses pancreatic-duodenal homeobox 1 (PDX1), detected starting from E8.5 in the mouse embryos in early progenitors and restricted to the $\beta$-cells at the late developmental stage (Guz et al. 1995). Targeted disruption of the $P d x 1$ gene in mice as well as homozygous mutation in human causes pancreas agenesis (Ahlgren et al. 1996, Stoffers et al. 1997), indicating its essential function in the morphogenesis and differentiation of the pancreas. The basic helix-loop-helix transcription factor neurogenin 3 (NEUROG3) is expressed transiently in the pancreatic endocrine progenitors (Apelqvist et al. 1999). Neurog3-deficient mice lack all pancreatic endocrine cell types (Gradwohl et al. 2000), indicating that it is required for differentiation of these cells. Further identification of the factors or co-factors involved in endocrine cell development would help to better understand the mechanisms implicated in this procedure. Considering the advance in the development of the pancreatic endocrine cells and available approaches allowing overcoming the lethality of Men 1 null embryos, we decided to determine the possible involvement of menin in the development of the pancreatic endocrine cells. In the current study, we have combined different genetic approaches to investigate the role of menin in pancreas development of the mouse. Our data provide compelling evidence showing that menin is essential for the development of the pancreatic endocrine cells and its absence results in the deficient formation of NEUROG3-positive cells, a key factor in this process.

\section{Materials and Methods}

\section{Men1 knockout mice and generation of chimeric mice}

Mice carrying the targeted Men 1 allele $\left(\operatorname{Men} 1^{\mathrm{T} / \mathrm{T}}\right)$ or the deleted Men 1 allele $\left(\operatorname{Men} 1^{\Delta / \Delta}\right)$ were used in the present study.
Both genotypes are null mutation in mice as described previously (Bertolino et al. 2003a). All animal experiments were conducted in accordance with the standards of human animal care and were approved by IARC's Animal Care and Use Committee.

For establishing Men 1 null ES cell lines, Men $1^{+/ T}$ mice were inter-crossed. Blastocysts were flushed from the uteri of pregnant female mice at day 3.5 post coitum and cultured individually on a murine fibroblastic cell layer for 5 days, in Dulbecco's modified Eagle's medium (15\% fetal calf serum, $2 \mathrm{mM}$ L-glutamine, $1 \mathrm{mM}$ sodium pyruvate, $0.1 \mathrm{mM}$ nonessential amino acids, $100 \mathrm{U} / \mathrm{ml}$ penicillin, $100 \mu \mathrm{g} / \mathrm{ml}$ streptomycin, $0.1 \mathrm{mM} \beta$-mercaptoethanol and $10 \mathrm{ng} / \mathrm{ml}$ murine leukaemia inhibitory factor (Chemicon International, Temecula, CA, USA). The blastocysts were then dissociated with trypsin/EDTA, and put into culture for 7 days on a murine fibroblastic cell layer. Finally, the ES cells were amplified and karyotyped. To generate chimeric mice, two clones each of Men 1 wild-type and $M e n 1^{\mathrm{T} / \mathrm{T}}$ ES cells were microinjected into blastocysts of C57BL/6 mice and transferred into pseudo-pregnant females.

\section{Pancreas bud culture}

The live embryos were harvested on E12.5. The pancreatic primordium was dissected and cultured on a filter (Millipore, Guyancourt, France) with RPMI 1640 medium (Invitrogen) containing penicillin $(100 \mathrm{U} / \mathrm{ml})$, streptomycin $(100 \mu \mathrm{g} / \mathrm{ml})$, HEPES $(10 \mathrm{mmol} / \mathrm{l})$, L-glutamine $(2 \mathrm{mmol} / \mathrm{l})$, non-essential amino acids $(1 \times$, Gibco), and 10\% heat-inactivated serum (Hyclone, Logan, UT, USA) was added. Cultures were maintained at $37^{\circ} \mathrm{C}$ in humidified $95 \%$ air, $5 \% \mathrm{CO}_{2}$.

\section{Mouse islet isolation}

Pancreatic islets were isolated from mice according to the protocol previously described (Bertolino et al. 2003c). Briefly, $2 \mathrm{ml}$ of $1 \mathrm{mg} / \mathrm{ml}$ collagenase (SERVA, Heidelberg, Germany) in Hank's buffered saline solution was injected into the pancreas through the bile duct. Pancreases were then removed and incubated for $20 \mathrm{~min}$ at $37^{\circ} \mathrm{C}$ and dissociated by mechanical pipetting. Islets were hand-picked from darkfield dishes under a dissecting microscopy.

\section{Tissue collection and fixation}

Tissues of chimeric mice were collected between 3 and 4 weeks after birth. Embryos were collected at different embryonic stages between E11.5 and E18.5. These tissues were fixed in $4 \%$ buffered formaldehyde and embedded in paraffin. The pancreatic rudiments were fixed at the end of the culture period in $4 \%$ buffered formaldehyde, preembedded in agarose (4\% of type VII low gelling temperature agarose (Sigma)), followed by embedding in paraffin. 
Histological, immunohistochemical and immunofluorescence analyses

For embryos and the pancreas of the chimeras, $3 \mu \mathrm{m}$ sections were used either for staining with haematoxylin and eosin for histological analyses or for immmunohistochemistry (IHC) and immunofluorescence (IF) staining as described previously (Bertolino et al. 2003b). Primary antibodies used were goat anti-menin C19 (1:500, Santa Cruz, CA, USA), rabbit antiPDX1 (1:10 000 (Duvillie et al. 2003)) and mouse monoclonal anti-NEUROG3 (clone F25A1B3, 1:9000, DSHB). When using mouse antibodies as primary antibodies, Vector M.O.M. immunodetection kit was used (Vector Lab, Burlingame, CA, USA). For 5-bromodeoxyuridine (BrdU) analysis, bud cultures were incubated for $1 \mathrm{~h}$ with $10 \mu \mathrm{M}$ BrdU (Sigma) before tissue fixation, then BrdU incorporation was evaluated by IHC using anti-BrdU antibody (Clone BU33 - Sigma). Primary antibodies used for IF experiments were guinea pig anti-insulin (1:500, Dako, Capintaria, CA, USA), rabbit anti-glucagon (1:600, NovoCastra, Milton Keynes, UK), anti-mucin-1 (1:200, Neomarkers, Fremont, CA, USA) and goat anti-menin (C19, 1:500).

For cultured pancreatic rudiments, $4 \mu \mathrm{m}$ sections were processed for IF staining as previously described (Bhushan et al. 2001). The following antibodies were used: mouse antihuman insulin (1/2000, Sigma), rabbit anti-glucagon (1:1000, Diasorin, Stillwater, MN, USA), and rabbit anti-carboxypeptidase A (CPA1; 1:600, Biogenesis, Poole, UK). Quantification of the insulin- and glucagon-positive cells was performed with an IPLab 3.7 Eval software.

Apoptosis was examined on tissue sections by TUNEL staining using the ' in situ cell death detection' kit (Roche) and counterstained with DAPI (Vector Lab). Double TUNEL and glucagons analysis was done by combining the abovementioned corresponding protocols.

\section{In situ hybridization}

For in situ hybridization, embryo tissues were fixed at $4{ }^{\circ} \mathrm{C}$ in $4 \%$ paraformaldehyde in PBS, cryoprotected in $15 \%$ sucrose $-7 \cdot 5 \%$ gelatin in PBS and frozen at $-50{ }^{\circ} \mathrm{C}$ in isopentane. Cryosections (14 $\mu \mathrm{m}$ in sickness) were prepared. The Neurog3 probe $(726 \mathrm{bp}$ ) was prepared as previously described (Ravassard et al. 1997). Plasmids were linearized and used as templates for synthesizing sense or antisense riboprobes using T7 or SP6 RNA polymerase (Roche), in the presence of digoxygeninUTP (Roche). In situ hybridization was performed as described previously (Duvillie et al. 2006), and colorimetric revelation was performed with 5-bromo-4-chloro-3-indolyl phosphate (Promega) and nitroblue tetrazolium (Roche), to obtain a blue precipitate. Photographs were taken using a Hamamatsu C5810 cooled 3CCD camera. No signal was obtained when a sense riboprobe was used.

\section{PCR and quantitative RT-PCR}

For PCR analysis of chimerism, genomic DNA was isolated from chimeric tissues at age of 3 weeks. The following primers were used: NEO1-FW: 5'-GATGGATTGCACGCAGGTTC-3'; NEO1-RV: 5'-CAGGTCGGTCTTGACAAAAAG-3'; B2-FW: 5'-CACCGGAGAATGGGAAGCCGAA-3'; B2-RV: 5'-TCCACACAGATGGAGCGTCCAG- $3^{\prime}$.

For RT-PCR analysis, total RNA was prepared from E12.5 wild-type and $\operatorname{Men} 1^{\Delta / \Delta}$ pancreas buds using Tri-Reagent (Sigma) according to the protocol provided by the manufacturer. Total RNA $(0.5 \mu \mathrm{g})$ was reverse transcribed with $0.5 \mu \mathrm{g}$ oligo-dT using M-MLV (Invitrogen). First-strand cDNA was used for real-time PCR with the Light cycler instrument, except for Neurog3, and FastStart DNA Master SYBR Green I kit (Roche). Primers were designed with Primer3 software (primer3_www.cgi v $0 \cdot 2$ - Whitehead Institute/MIT, Cambridge, MA, USA) and were as follows: HES1-FW: $5^{\prime}-$ GAAAGATAGCTCCCGGCATT-3'; HES1-RV: 5'-ACCTCGTTCATGCACTCGC-3'; PDX1-FW: $5^{\prime}$-CATCTCCCCATACGAAGTGC-3'; PDX1-RV: 5'-TGTAGGCAGTACGGGTCCTC-3'; ONECUT1-FW: 5'-AGACCTTCCGGAGGATGTG-3'; ONECUT1-RV: 5'-TTGGACGGACGCTTATTTTC-3'; FOXA2-FW: 5'-GACATACCGACGCAGCTACA-3'; FOXA2-RV: 5'-GAGAAAGCAGTCGTTGAAGG-3'; HPRT1-FW: 5'-TGTTGTTGGATATGCCCTTG-3'; HPRT1-RV: 5'-AACTTGCGCTCATCTTAGGC- $3^{\prime}$. Serially diluted cDNA samples or PCR products were used to calculate the efficiency of each PCR with RealQuant software (Roche). After an initial Taq activation at $95^{\circ} \mathrm{C}$ for $10 \mathrm{~min}$, Light cycler PCR was performed using 45 cycles with the following cycling conditions: $95^{\circ} \mathrm{C}$ for $15 \mathrm{~s}$, $62{ }^{\circ} \mathrm{C}$ for $5 \mathrm{~s}$, and $72{ }^{\circ} \mathrm{C}$ for $16 \mathrm{~s}$. The Hprt 1 transcript was used as internal standard to control the amplification variations.

For real-time PCR of Neurog3, we used the primers as followed: NEUROG3-FW 5'-TTCGCCCACAACTACATCTG-3'; NEUROG3-RV 5'-TTGGGAGACTGGGGAGTAGA-3', cyclophilin A-FW 5'-CAGGTCCTGGCATCTTGTTC-3'; cyclophilin A-RV $5^{\prime}$-TTGCTGGTCTTGCCATTCCT- $3^{\prime}$ using a SYBR Green PCR master Mix, Applied Biosystem (Foster City, CA, USA) according to the instructions of the manufacturer. For both PCR analyses, the mean of the control samples was set as 1 to normalize the results.

\section{Statistical analysis}

All values are expressed as means \pm s.D. Statistical significance was determined by using the two-tailed unpaired Student's $t$-test, and differences were considered to be statistically significant when $P<0 \cdot 05$.

\section{Results}

\section{Menin is expressed in the developing pancreas}

To investigate the role of menin in pancreas development in the mouse, we first analysed the menin expression pattern in 
embryonic pancreata of wild-type mice at different developmental stages respectively at E11.5, E12.5, E13.5, E15.5, E16.5 and E18.5. Menin protein was detected by immunostaining with anti-menin antibodies in the entire pancreatic epithelium and surrounding tissues throughout the developmental stages (Fig. 1A-F). To ensure that menin is expressed in both endocrine and ductal cells, which constitute minor cellular compartments in pancreata, we performed IF staining of menin in combination with the pancreatic cell-specific markers on E16.5 pancreata. The results showed that menin was detected in insulin- and glucagon-expressing endocrine cells as well as Mucin1-expressing ductal cells (Fig. 1G-I), indicating that menin is expressed in these cell populations in developing pancreas.

Reduced number of glucagon-expressing cells in pancreata associated with apoptosis in E12.5 Men1 null embryos

We performed histological and IHC analyses on E12.5 pancreata, prior to the embryonic lethality of Men 1 null embryos (Bertolino et al. 2003a, Crabtree et al. 2003). At this stage, pancreases undergo the first transition of endocrine cell differentiation and display glucagon-positive cells. The viability of all the analysed embryos was assessed by heartbeating. Both histological and IHC analyses were initially carried out at more than three different positions for each embryo. For those embryos where no glucagon staining was detected, the remaining tissues have been further subjected to the same analysis to confirm the result. The whole pancreata appeared histologically normal in E12.5 Men 1 null embryos (Fig. 2B and C), the branching of pancreatic bud rudiment being not significantly different from that seen in control embryos (Fig. 2A). However, the glucagon-expressing cells were either absent, in four out of seven E12.5 Men1 null pancreata (Fig. 2E), or very few (Fig. 2F) in the remaining (three out of seven) compared with Men 1 wild-type embryos. These observations suggest that menin is required to support the differentiation or the survival of glucagonexpressing cells at this stage. To investigate whether the reduced number of glucagon-positive cells is associated with apoptosis, TUNEL assay was applied to analyse these developing pancreata. Indeed, apoptotic cells were detected in three out of four E12.5 Men1 null embryos devoid of glucagon-positive cells, whereas they were completely absent in control embryos (Fig. 2G-L, Table 1). To further determine whether the absence of menin may trigger
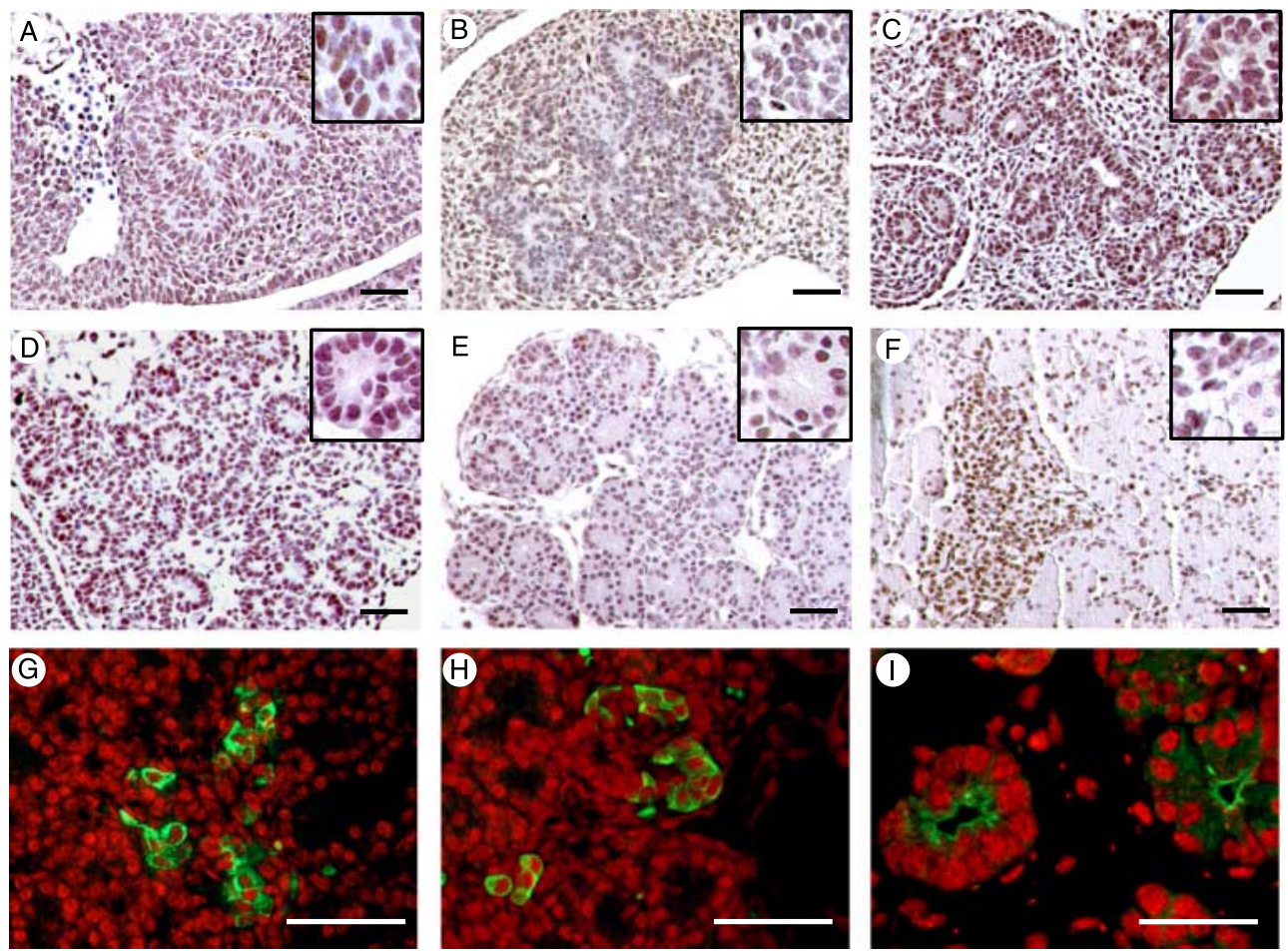

Figure 1 Menin is expressed in the developing pancreas. Immunostaining of menin in developing pancreas at various stages: (A) E11.5, (B) E12.5, (C) E13.5, (D) E15.5, (E) E16.5, (F) E18.5. Insets show an amplified view of a part of pancreatic epithelium. The scale bars are $50 \mu \mathrm{m}$. (G-I) Double immunofluorescence of islet subpopulations of E16.5 pancreata using antibodies against menin (red), insulin (G, green), glucagon ( $\mathrm{H}$, green) and mucin-1 (I, green). The scale bars are $50 \mu \mathrm{m}$. Full colour version of this figure available via http://dx.doi. org/10.1677/JOE-08-0289. 
apoptosis in glucagon-positive cells, we carried out glucagon and TUNEL double staining. Indeed, a substantial proportion of glucagons-positive cells (70\%) were found apoptotic in five Men1 null pancreata having glucagonpositive cells (Fig. 2M-P). Such double-positive cells were not seen in four Men1 wild-type control. These results suggest that menin prevents apoptosis in glucagon-secreting cells at this stage.

To gain insights into the molecular mechanisms responsible for the reduced number of glucagon-positive cells in Men1 null embryos at E12.5, we examined the expression of several key genes in pancreas development, including $H n f 3 \beta$ ((Lee et al. 2001), currently called Foxa2), Onecut1 (Jacquemin et al. 2000), Pdx1 (Jonsson et al. 1994), Hes 1 (Jensen et al. 2000) and Neurog3 (Gradwohl et al. 2000) by real-time PCR (Fig. 2Q and R) and immunostaining of PDX1 (Fig. 2S) and NEUROG3 (Fig. 2T). We found no detectable alteration of their expression in E12.5 Men1 null pancreata analysed, suggesting that the role played by menin in the glucagonpositive cells at this stage is not likely via regulating gene expression of these factors.

Men1 null mutant ES cells failed to contribute normally to the formation of the pancreatic endocrine cells in chimeric mice

To determine whether the role of menin in the development of the pancreatic endocrine cells was due to the cell autonomous effects of menin, we next examined the capacity of Men 1 null ES cells to differentiate into the pancreatic endocrine cells by chimerism assay. To this end, two Men 1 wild-type and two Men 1 null ES cell lines were independently established from blastocysts derived from inter-crosses of heterozygous Men 1 mutant mice. After ascertaining their karyotype and ensuring that their gene expression profile corresponded to totipotent ES cells (Supplemental Fig. 1, see Supplementary data in the online of version of the Journal of Endocrinology at http://joe. endocrinology-journals.org/content/vol199/issue2/), they were injected into Men 1 wild-type C57BL/6 blastocysts to generate chimeric mice. The proportion of Men 1 null ES cell derivatives in the pancreatic islets of 3-week-old chimeric mice was then assessed by IHC (Fig. 3B-F and $\mathrm{K}$ ) and DNA genotyping respectively (Fig. 3L). IHC analysis of six chimeric mice generated with Men 1 null ES cells using anti-menin antibodies revealed that, while mixed populations of menin-positive and -negative cells could be detected in the pancreatic exocrine compartment and in adjacent tissues (Fig. $3 \mathrm{~B}$ and $\mathrm{C}$ ), the islets were mainly composed of menin positively stained cells (Fig. 3D-F). Quantification of the chimerism by IHC analysis showed that more than $85 \%$ of islets contain more than $80 \%$ of menin-positive cells (Fig. 3K). In these islets, the lack of Men1 null ES cell derivatives was seen both in $\alpha$ - and $\beta$-cells, as demonstrated by double IF staining (Fig. 3G-J). The data indicate that the majority of Men 1 null ES cells failed to contribute to the formation of pancreatic islet cells.

In parallel, the contribution of Men 1 null ES derivatives in the islets of five chimeric mice was evaluated by quantifying the targeted Men 1 allele using real-time PCR. Compared with the skin, arbitrarily set as the reference tissue, the amount of Men 1 null ES derivatives in the islets is reduced $42 \%$, and is only $47 \%$ of that found in the exocrine pancreas (Fig. 3L). Taken together, the chimerism assay revealed the impaired capacity of Men 1 null ES cells to differentiate in vivo into the pancreatic endocrine cells, albeit the presence of neighbouring Men 1 wild-type cells. These data indicate a cell-specific autonomous effect of menin in controlling pancreatic endocrine cell development. This observation, in consistence with our previous work (Bertolino et al. 2003a), also shows that lack of the Men 1 gene has no ubiquitous effect on the development of different cell types analysed, and supports the hypothesis that menin is specifically involved in endocrine development in the pancreas.

Menin is required for the normal development of the pancreatic endocrine, but not exocrine cells in pancreatic bud cultures

The embryonic lethality of Men1 null embryos after E12.5 hampers the investigation of menin's role in the second transition of the endocrine pancreas. Therefore, to address this issue, we performed the pancreatic bud culture, which allows recapitulating of the second transition of endocrine cell differentiation (Duvillie et al. 2003, 2006, Attali et al. 2007). It was previously established that the cultured pancreases can develop exocrine and endocrine cells in the defined conditions, and the in vitro expression pattern of the major transcription factors found in the cultured pancreases, including NKX6-2, NEUROG3, PAX4, NEUROD1 and the markers of the mature $\beta$-cells PCSK1, PCSK2 and ABCC8, were similar to that found in vivo (Attali et al. 2007). Two independent series of pancreatic bud cultures using E12.5 Men1 wild-type $(n=7)$ and Men1 null $(n=6)$ heartbeating embryos were carried out. The development of endocrine and exocrine cells was evaluated after 7 days culture. Insulin/CPA1 double immunostaining revealed that, compared with the controls, Men1 null pancreatic buds exhibited a significant reduction in the number of insulinpositive cells, while CPA1 staining for exocrine cells in the same sample was normal, indicating that the absence of menin resulted in failure of endocrine cell development without affecting that of exocrine pancreas (Fig. 4A-H and Q). Importantly, by insulin/glucagon double immunostaining, we found that the development of both $\alpha$ - and $\beta$-cells was clearly affected in Men 1 null cultured pancreatic buds (Fig. 4I-P, and $\mathrm{R})$, indicating that the need of menin is therefore not restricted to a specific type of pancreatic endocrine cells. These findings are consistent with the observation made by IHC and IF analysis in chimeric mice. 

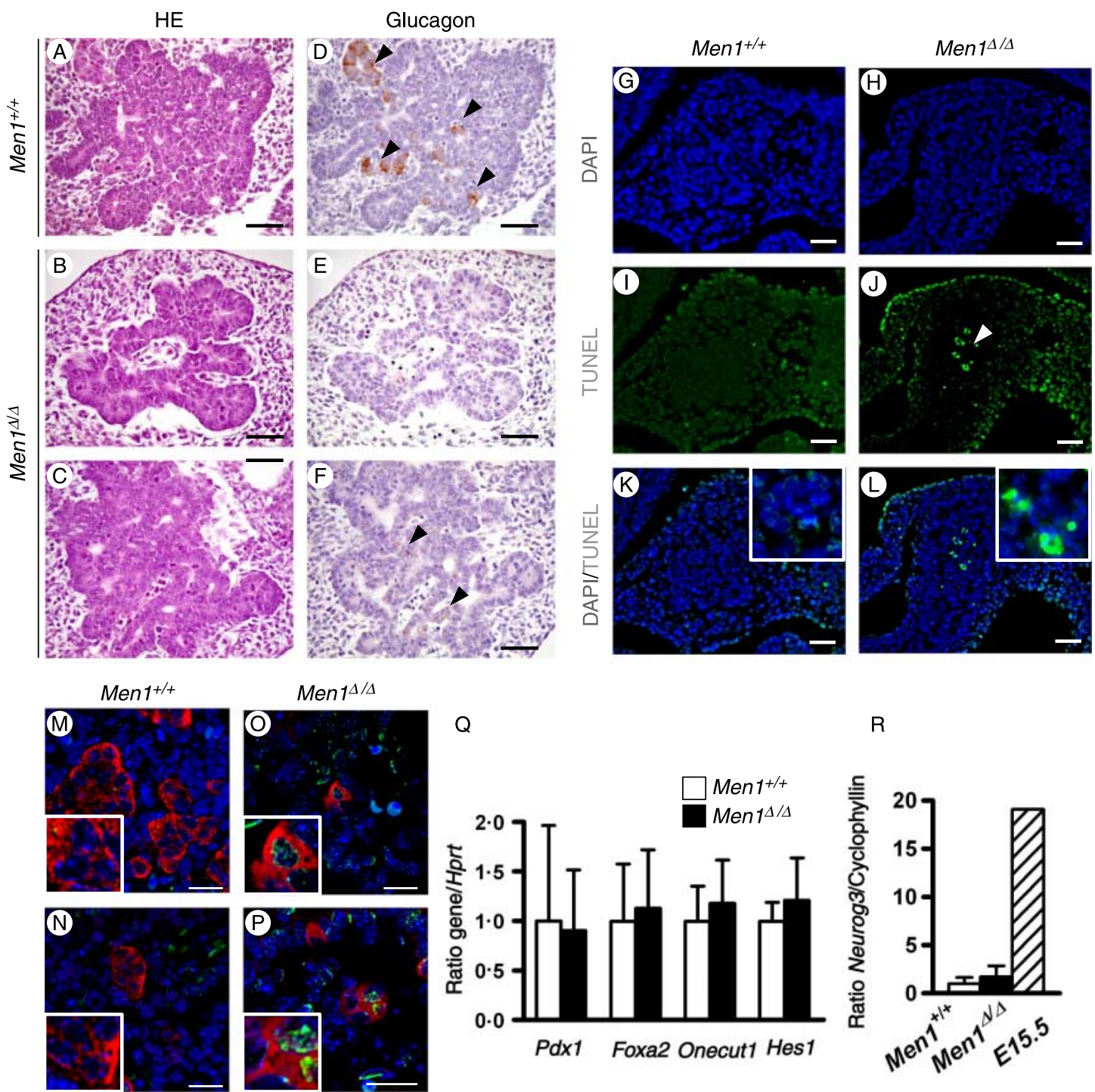

$\mathrm{R}$

DAPI/TUNEL/Glucagon
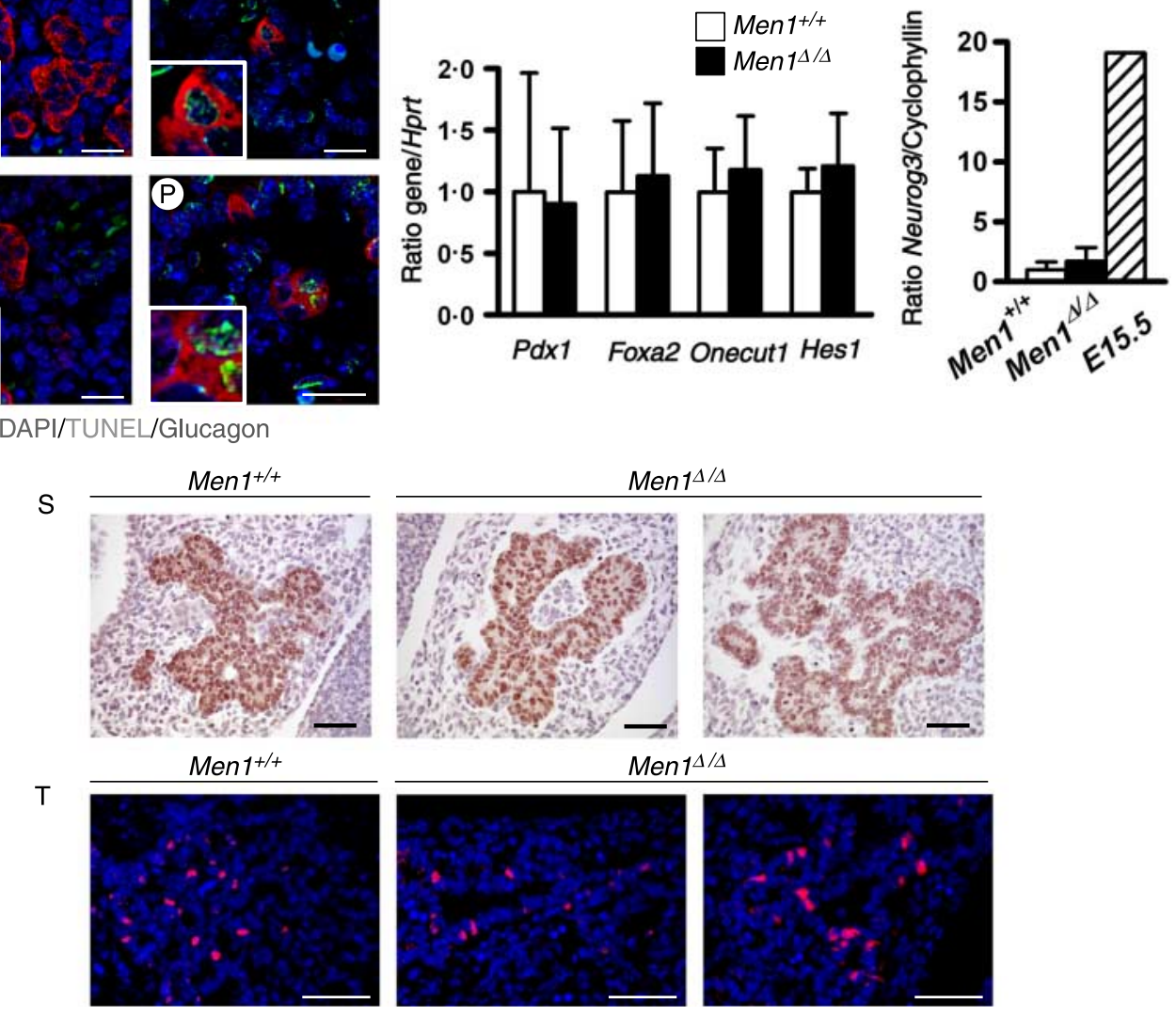
Table 1 Abnormal development of the pancreatic endocrine cell in E12.5 Men1 null mutant embryos. Summary of the results obtained from glucagon detection and TUNEL analysis.

\begin{tabular}{|c|c|c|}
\hline & Glucagon staining & Apoptosis \\
\hline \multicolumn{3}{|c|}{ Men1 $^{+/+}$} \\
\hline 1 & + & - \\
\hline 2 & + & - \\
\hline 3 & + & - \\
\hline 4 & + & - \\
\hline 5 & + & - \\
\hline 6 & - & - \\
\hline \multicolumn{3}{|c|}{ Men $^{\Delta / \Delta}$} \\
\hline 1 & Weak & - \\
\hline 2 & Weak & - \\
\hline 3 & Weak & - \\
\hline 4 & - & - \\
\hline 5 & - & + \\
\hline 6 & - & + \\
\hline 7 & - & + \\
\hline
\end{tabular}

Six control $\left(M e n 1^{+/+}\right)$and seven Men $1^{\Delta / \Delta}$ embryos were analysed and are shown.

Lack of menin results in altered structure and aberrant cell differentiation in cultured buds

We noticed that a substantial proportion (seven out of nine) of the Men 1 null pancreatic buds cultured at day 7 formed cystic structures that varied in size in different cultured buds (Fig. 5A-C). Similar cysts were not seen in Men 1 wild-type control (Fig. 5A). The formation of cystic structures in pancreas is considered to be a consequence of abnormal cellular differentiation of either ductal or endocrine cells (Cano et al. 2004, Pierreux et al. 2006). Indeed, we found that cells lining the cysts in Men 1 null pancreatic bud culture were negatively stained with the antibodies against PDX1 and Mucin-1 respectively the mature pancreatic $\beta$-cell and ductal cell markers (Fig. 5D-F and G-L). Further analysis showed the lack of both insulin- and glucagon-secreting cells within large cystic structures in cultured Men 1 null pancreatic buds at day 7 (Supplemental Fig. 4, see Supplementary data in the online of version of the Journal of Endocrinology at http:// joe.endocrinology-journals.org/content/vol199/issue2/). All these data indicate that the cysts are delineated by an epithelium that follows neither mature $\alpha$ - and $\beta$-cell nor ductal cell fate. Our work demonstrates that the lack of menin altered the cellular differentiation of the pancreatic cells.
Markedly decreased number of Neurog3-expressing cells in the absence of menin in day 2 Men1 null pancreatic bud cultures

To investigate the possible molecular and cellular events leading to the aberrant pancreatic endocrine cell development in the absence of menin in bud culture, we analysed the number of cells expressing Neurog3, a key factor for the pancreatic endocrine cell development (Gradwohl et al. 2000) after 2 days of culture, where its expression reaches the highest level in normal cultured buds. We found that the number of Neurog3-expressing cells was markedly decreased in day 2 Men 1 null pancreatic bud cultures $(n=5)$ compared with Men 1 wild-type controls $(n=4$; Fig. $6 \mathrm{~A}-\mathrm{E})$. On the other hand, neither the cell proliferation analysed by BrdU staining (Fig. 6F and $\mathrm{G}$ ), nor the cell death determined by TUNEL assay (Fig. 6H-M) showed any difference between Men 1 null and wild-type cultured pancreatic buds at this time point. We also noticed that there was no obvious morphological alteration in day 2 Men 1 null cultured pancreatic buds (data not shown). The abnormal pancreatic endocrine cell development and the decreased number of Neurog3-expressing cells in cultured Men1 null pancreatic buds are reminiscent of the phenotype of Neurog3 mutant mice (Gradwohl et al. 2000). The data suggest that the reduced Neurog3-expressing cell number in the Men1 null pancreatic bud cells could be the primary event leading to the observed defects.

\section{Discussion}

Based on its complete inactivation in MEN1 tumours, menin is considered to play a critical role in the control of cell growth in adult endocrine cells affected in the disease, including pancreatic endocrine $\alpha-, \beta$ - and PP cells, whereas its in vivo physiological function in these cells remains to be elucidated. Using different genetic approaches, we show that menin is a novel factor essential for the development of the pancreatic endocrine cells, including both $\alpha$ - and $\beta$-cells. We also demonstrate that menin is required neither for the formation of the pancreatic buds nor for development of the exocrine pancreas, indicating clearly that the effect of menin in the pancreas is endocrine cell specific. More importantly, chimerism analysis demonstrates that the presence of surrounding menin-expressing cells is not sufficient to allow

Figure 2 Reduced number of glucagon-positive cells in pancreatic bud associated with apoptosis in E12.5 men1 null embryos. (B-F) Microscopic images of Men $1^{\Delta / \Delta}$ and (A and D) Men $1^{+/+}$control pancreata sections stained with (A-C) HE and (D-F) antibodies against glucagon. Arrowheads indicate cells expressing glucagon. The scale bars are $50 \mu \mathrm{m}$. Microscopic images of Men $1^{\Delta / \Delta}$ and Men $1^{+/+}$control pancreata sections stained with DAPI (G and H, blue), for apoptosis by TUNEL assay (I and J, green) and merged images (K-L). Arrowhead shows TUNEL-positive signal. Insets show an amplified view of a part of pancreatic bud. The scale bars are $50 \mu \mathrm{m}$. (M-P) Representative double TUNEL and glucagon staining of $\operatorname{Men} 1^{\Delta / \Delta}(n=5)$ and control pancreata (Men $\left.1^{+/+}, n=4\right)$ serial sections from two independent experiments. The scale bars are $24 \mu \mathrm{m}$. (Q) Quantitative RT-PCR analysis of gene expression of $P d x 1$, Foxa2, Onecut1 and Hes1 in E12.5 Men1 wild-type $\left(\right.$ Men $1^{+/+} ;$white bar, $\left.n=6\right)$ and Men 1 null (Men $1^{\Delta / \Delta}$; black bar, $n=5$ ) pancreata. Hprt1 was used as an internal control. (R) Quantitative RT-PCR analysis of Neurog3 expression in E12.5 Men 1 wild-type (Men $1^{+/+}$; white bar, $\left.n=4\right)$ and Men 1 null (Men $1^{1 / \Delta}$; black bar, $\left.n=4\right)$ pancreata. An E15.5 Men 1 wild-type pancreata was used as the positive control (hatched bar). Cyclophyllin was used as an internal control. (S) Immunohistochemical and (T) immunofluorescence analyses of E12.5 Men 1 wild-type (Men $\left.1^{+/+}\right)$and Men 1 null $\left(M e n 1^{\Delta / 4}\right)$ pancreas sections stained with the antibody against PDX1 (S) and NEUROG3 (T). The scale bars are $50 \mu \mathrm{m}$. Full colour version of this figure available via http://dx.doi.org/10.1677/JOE-08-0289. 

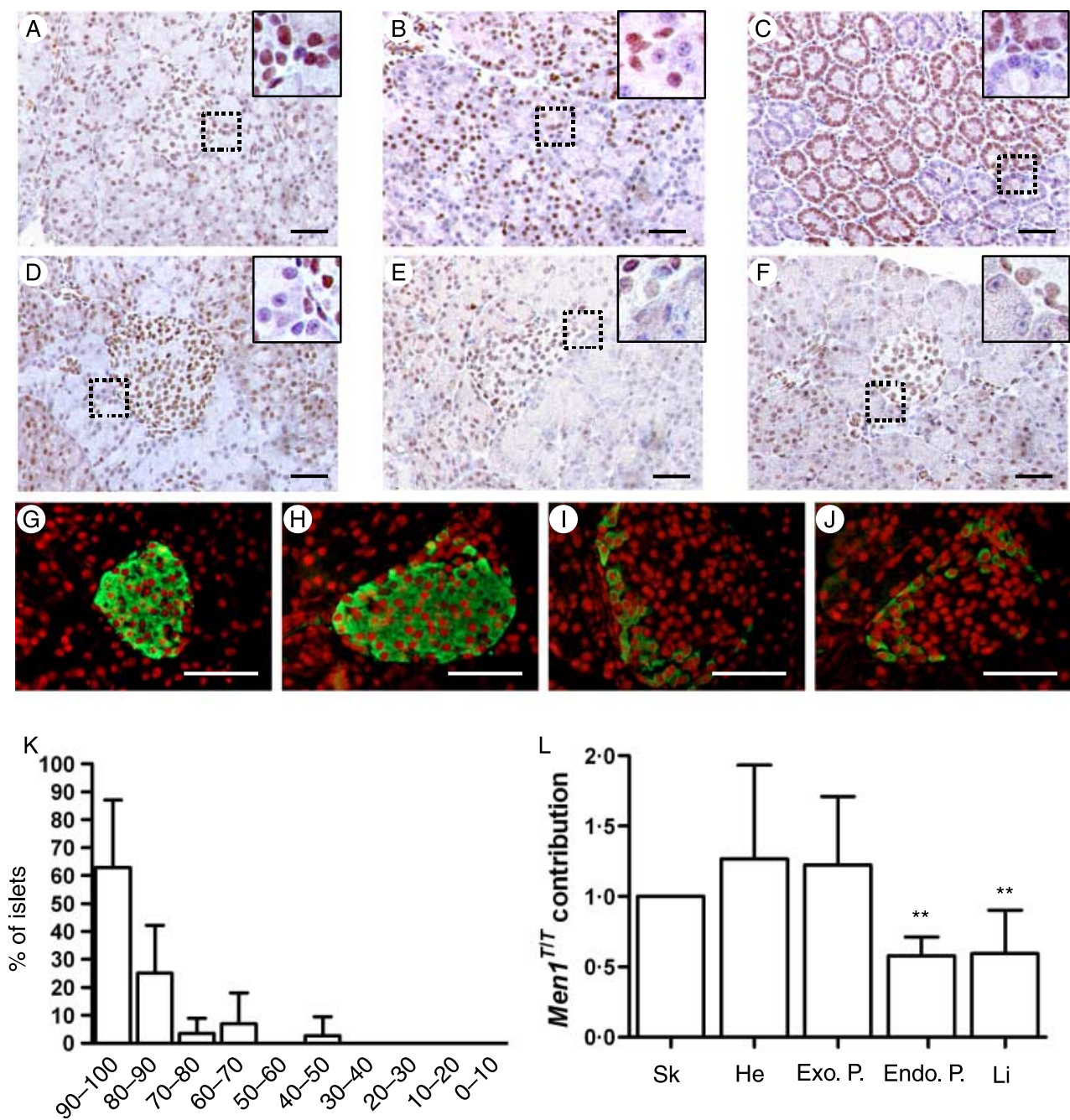

$\%$ of menin positive cells

Figure 3 Men 1 null mutant ES cells fail to contribute to the formation of the pancreatic endocrine cells in chimeric mice. (A-F) Immunohistochemistry analysis of contribution of Men $1^{T / T}$ cells to endocrine pancreas analysed by menin antibody on 3-week-old chimeric mice. The scale bars are $50 \mu \mathrm{m}$. (A) Pancreas of control mice generated by micro-injection of Men 1 wild-type ES cells. (B-G) Chimeric mice generated with micro-injection of Men $1^{T / T}$ ES cells: (B) exocrine pancreas, (C) intestine, (D-F) endocrine pancreas of three different chimeric mice. Note that the exocrine tissue shows a mixture of menin-negative and -positive cells. (G-J) Double immunofluorescence of pancreas of ( $\mathrm{G}$ and $\mathrm{I}$ ) control and ( $\mathrm{H}$ and $\mathrm{J}$ ) chimeric mice, showing the lack of Men $1 \mathrm{null}$ ES cell derivatives in islets from the latter in both in $\alpha$ - and $\beta$-cells. The scalebars are $50 \mu \mathrm{m}$. $(\mathrm{G}-\mathrm{H})$ Double staining with menin (red) and insulin (green). (I-J) Double staining with menin (red) and glucagon (green). (K)

Quantification of menin-positive cells in the islets of six chimeric mice generated with micro-injection of Men $1^{T / T}$ ES cells and stained by immunohistochemistry. To avoid a chimerism bias, only the islets situated in chimeric exocrine surroundings were scored. Between 6 and 15 (average 10) islets were scored for each chimeric mice. (L) The contribution of the Men $1^{T / T}$ ES cell derivatives were analysed by the presence of the Men 1 targeted allele $\left(\right.$ Men $\left.1^{T / T}\right)$ in different tissues of five chimeric mice using real-time PCR, after normalization with the mouse $B 2$ gene as internal control. That of the skin is arbitrarily set as 1 . Note that the contribution of the Men $1^{T / T}$ ES cell derivatives to the liver is half of that to the skin $\left({ }^{* *} P<0 \cdot 01\right)$, consistent with previous report (Bertolino et al. 2003a). Tissue abbreviations are as follows: Sk, skin; He, Heart; Exo. P., exocrine pancreas; Endo. P., endocrine pancreas; $\mathrm{Li}$, Liver. Full colour version of this figure available via http://dx.doi.org/10.1677/JOE-08-0289.

the Men1 null ES derivatives to develop into the islet cells, indicating an intrinsic need of menin in the pancreatic endocrine cells. Finally, we found that the inactivation of the Men 1 gene affects the development of the pancreatic endocrine cells before the second transition of cellular differentiation of these cells. Our data thus indicate the importance of menin in both the early glucagon-expressing endocrine cells and the initial steps of the major pancreatic endocrine cell 


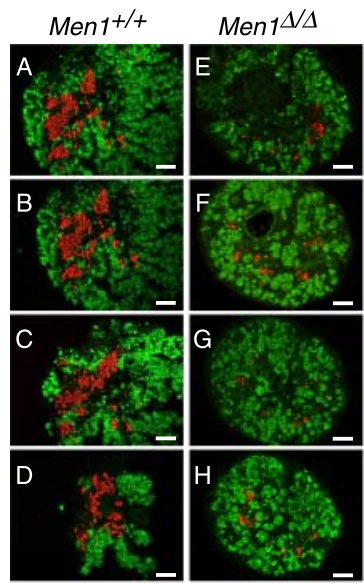

Insulin / CPA
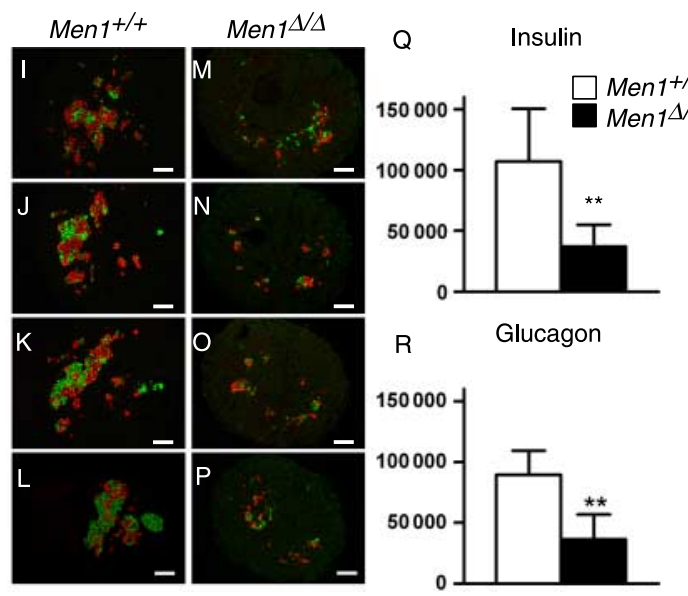

Insulin / glucagon
Figure 4 Menin is specifically required for normal development of the endocrine pancreas in pancreatic bud cultures. (A-H) Representative serial images of pancreatic bud cultures co-stained with antibodies against insulin (red) and carboxypeptidase A (CPA1, green). The scale bars are $100 \mu \mathrm{m}$. Note that the corresponding whole serial images are shown in Supplemental Fig. 2, see Supplementary data in the online of version of the Journal of Endocrinology at http://joe.endocrinology-journals.org/content/vol199/ issue2/. (I-P) Representative serial images of pancreatic bud cultures co-stained with antibodies against insulin (red) and glucagon (green). The scale bars are $100 \mu \mathrm{m}$. Note that the corresponding whole serial images are shown in Supplemental Fig. 3, see Supplementary data in the online of version of the Journal of Endocrinology at http://joe.endocrinology-journals.org/content/vol199/issue2/. (Q-R) Quantification of positive staining signals in above immunostaining analyses in control $\left(M e n 1^{+/+}\right.$, white bar, $\left.n=7\right)$ and in Men 1 null pancreatic bud culture (Men $1^{\Delta / 4}$, black bar, $n=6$ ) from two independent experiments. (Q) For each cultured bud, half sections were stained with insulin/CPA1 and insulin-positive signals were scored. (R) The other half was stained with insulin/glucagon and glucagon-positive signals were scored. The vertical axes represent mean value of the positive signals acquired for each bud $(* * P<0 \cdot 01)$. Full colour version of this figure available via http://dx.doi.org/10.1677/JOE-08-0289.
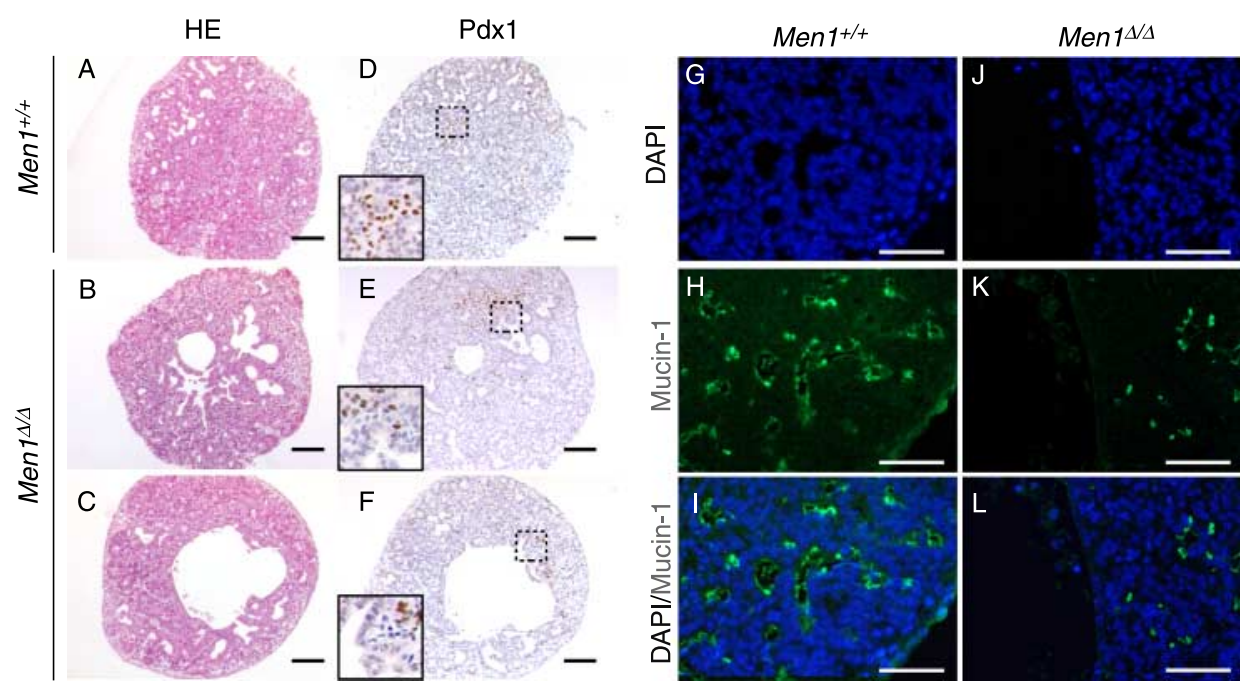

Figure 5 Men 1 disruption results in altered pancreatic structure and aberrant cellular differentiation in day 7 cultured pancreatic bud. (A-C) Microscopic images of serial sections of day 7 (d7) cultured pancreatic buds respectively with $\mathrm{H} \& \mathrm{E}$ staining and $(\mathrm{D}-\mathrm{F})$ immunostaining with antibodies against PDX1. Insets show an amplified view of a part of stained pancreatic bud culture. The scale bars are $100 \mu \mathrm{m}$. Microscopic images of d7 cultured pancreatic buds by co-staining with DAPI ( $\mathrm{G}$ and J, blue) and antibodies against Mucin-1 (green, $\mathrm{H}$ and $\mathrm{K}$ ). Lower is the merge ( $\mathrm{I}$ and $\mathrm{L}$ ). The scale bars are $50 \mu \mathrm{m}$. Full colour version of this figure available via http://dx.doi.org/10.1677/JOE-08-0289. 


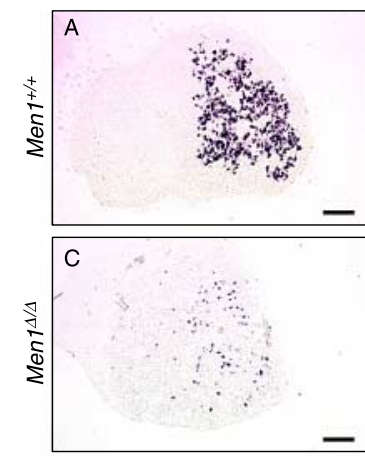

BrdU
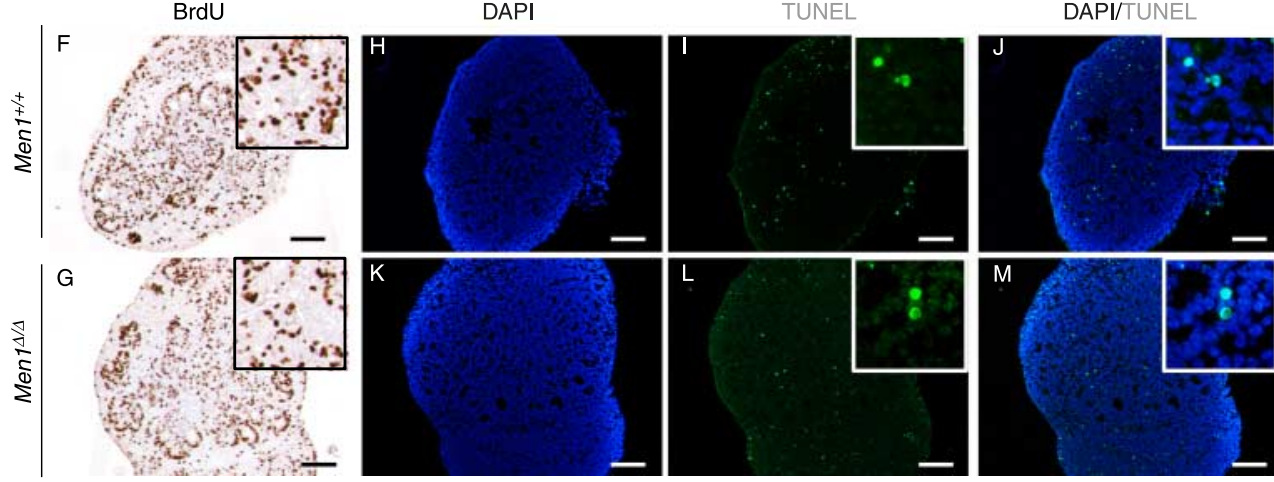

Figure 6 Markedly reduced number of Neurog3-expressing cells in day 2 (d2) Men1 null pancreatic bud cultures without alterations in cell proliferation or death. (A-D) In situ hybridization analysis of Neurog3 expression in $\mathrm{d} 2$ cultured pancreatic buds. Two representative images from one Men $1^{+/+}$control $(\mathrm{A}$ and $\mathrm{B})$ and one Men 1 null (Men $1^{\Delta / \Delta}, \mathrm{C}$ and D) bud are shown. The scale bars are $100 \mu \mathrm{m}$. (E) Neurog3-positive signals in control (white bar, $n=4$ ) and in Men1 null pancreatic bud culture (black bar, $n=5$ ) were scored in all sections of each. The vertical axis represents mean value of the positive signals obtained for each bud $\left({ }^{*} P<0 \cdot 01\right)$. Note that the corresponding whole serial images for Neurog3 in situ hybridization are shown in Supplemental Fig. 5, see Supplementary data in the online of version of the Journal of Endocrinology at http:// joe.endocrinology-journals.org/content/vol199/issue2/. (F-G) Microscopic images of d2 (F) Men1 $1^{+/+}$and (G) Men $1^{\Delta / \Delta}$ cultured pancreatic buds with BrdU staining. Microscopic images of $\mathrm{d} 2(\mathrm{H}-\mathrm{J}) \mathrm{Men}^{+/+}$and $(\mathrm{K}-\mathrm{M})$ Men 1 null $\left(\right.$ Men $^{\Delta / \Delta}$ ) cultured bud sections stained with DAPI (blue, $\mathrm{H}$ and K), analysed by TUNEL assay (green, I and L) and merged images ( and $M$ ). Insets show an amplified view of a part of pancreatic bud. The scale bars are $50 \mu \mathrm{m}$. Full colour version of this figure available via http://dx.doi.org/10.1677/JOE-08-0289.

development. However, the contribution of menin to the later stage of the major endocrine pancreas development could not be assessed in the current work. This would require either the application of siRNA in late wild-type pancreatic bud explants or temporally inducible disruption of a floxed Men1 allele. Also, we noticed that a small number of islets from chimeric mice injected with Men 1 null ES cells, less than $2 \%$ of examined islets, show a near-equal proportion of meninpositive and -negative cells. This, along with the observed presence of diminished, but not entirely absent, glucagonsecreting cells in some of the E12.5 Men $1^{-1-}$ embryonic pancreas, may suggest that the requirement of menin is either not absolute or can be biased by the occurrence of altered activities of other factors upon menin inactivation.

The reduced number of glucagon-expressing cells and the apoptotic glucagon positive cells were seen in E12.5 Men 1 null pancreata (under the first endocrine cell differentiation transition), suggesting that menin could play a role in cell survival in these cells at this early developmental stage.
However, we did not observe any alteration of cell death in Men 1 null pancreata cultured for 2 days, indicating that menin's role may imply different cellular functions in the second endocrine cell differentiation transition. Indeed, our data strongly suggest that menin is needed for the formation of NEUROG3-expressing cells during the crucial step of the second pancreatic transition where the progenitor cells commit to endocrine differentiation. We thus attribute the default of endocrine development in the cultured Men 1 null embryos to the lack of activated NEUROG3 expression rather than cell death.

Transgenic lineage tracing studies demonstrated that the early glucagon-expressing cells are unlikely to be the progenitors of later mature endocrine cells (Herrera 2000). Therefore, the developmental failure of the pancreatic endocrine cells at the second transition in the absence of menin cannot be simply explained by the lack of early glucagon-expressing cells. Conversely, we noticed that cystic structures appeared in cultured Men 1 null pancreatic buds, which are delineated with 
aberrantly differentiated cells. Considering the occurrence of deficient endocrine pancreas development, the formation of cystic structures in Men 1 null pancreatic bud cultures could be the consequence of abnormal cellular differentiation of cells lacking menin expression.

We did not detect any altered expression of major genes involved in the control of early pancreas development in E12.5 Men 1 null pancreata, including $P d x 1$ (Jonsson et al. 1994), Foxa2 (Lee et al. 2001), Onecut1 (Jacquemin et al. 2000) and Hes 1 (Jensen et al. 2000), as well as Neurog3. However, the number of Neurog3-expressing cells, fated to become endocrine cells during the second endocrine cell differentiation transition (Edlund 2002, Wilson et al. 2003), was severely decreased in day 2 Men 1 null pancreatic bud cultures. This discrepancy may be due to the different molecular mechanisms involved respectively in the first and the second pancreatic endocrine cell differentiation transitions. As menin is closely related to transcriptional regulation, it is plausible that menin is needed, directly or indirectly, for normal NEUROG3 expression at this second stage of endocrine pancreas development, by acting upstream of NEUROG3. Further studies are needed to determine in detail the role played by menin in regulating NEUROG3 expression and the fate of NEUROG3-expressing cells. We noticed that none of the currently known protein partners of menin has been reported to be involved in the regulation of the Neurog 3 gene. Recently, Smart et al. (2006) has reported that the TGFB1 pathway plays an important biological role in pancreas development, but mainly in maturation of differentiating $\beta$-cells. Obviously, the interaction of menin with SMAD proteins alone is not sufficient to explain its role found in this study, although we cannot exclude the possibility that it may participate in the TGFB1 pathway at the later stage of pancreas development.

Among numerous factors implicated in the development of the pancreatic endocrine cells, MEN1 is perhaps the first gene that is identified to be involved both in development and tumorigenesis of pancreatic endocrine cells. The seemingly contradictory biological effects of menin during embryonic development and the adult life of pancreatic endocrine cells indicate that menin plays fundamental but different roles during these two periods. This is reminiscent of another tumour suppressor, the $R b$ gene, which is not only responsible for the occurrence of retinoblastoma when inactivated, but also critically required for normal retinal development during the embryogenesis (MacPherson et al. 2004). Our data are also in consistency with the recent findings revealing multifaceted biological functions of menin in different cells and tissues reported by other groups (Sowa et al. 2003, Yokoyama et al. 2005). In particular, Sowa et al. (2003) have demonstrated that menin is required for the commitment of mesenchymal stem cells into the osteoblast lineage. By addressing the mechanisms of menin's essential function in the development of the pancreatic endocrine cells, one may know better physiological functions of menin, especially those implicated in the control of cellular differentiation and proliferation in endocrine cells. On the other hand, albeit identification of numerous factors responsible for the development of the pancreatic endocrine cells, many biological aspects of these cells remain to be elucidated. The identification of menin's role in this procedure should be of help not only for a better understanding of these cells, but also for the development of new therapeutic strategies for the treatment of the diseases affecting the pancreatic endocrine cells, including both tumours and metabolic disorders.

\section{Declaration of interest}

The authors declare that there is no conflict of interest that could be perceived as prejudicing the impartiality of the research reported.

\section{Funding}

This work was supported by Association pour la Recherche contre le Cancer (grant numbers: 3458, 4054 to C Z); Ligue contre le Cancer de la Loire and du Rhône (to $\mathrm{C} Z$ ); the 6th European Union Framework ( $\beta$-cell therapy integrated project to R S) and Association Française des Diabetiques (to R S). $\mathrm{S} F$ was the recipient of fellowships from the Ligue contre le Cancer de la Loire for 3 years, and the Association pour la Recherche contre le Cancer for the last 9 months.

\section{Acknowledgements}

We thank Marie-Pierre Cros and Dominique Galendo for the maintenance of the mouse colonies, Colette Piccoli for blastocyst preparation, Nicole Lyandrat for histological assistance, Virginie Aiello and Annie Basmaciogullari for technical assistance, Catherine Rey (Neurobiotec Service, Lyon) for help with quantitative RT-PCR. We are grateful to colleagues from GDR (Groupement de Recherche ou Réseau de laboratories) 2916, and to Dr P Bertolino for fruitful scientific discussion. Further thanks to Dr J I Loizou (IARC, Lyon, France) for her kind help in manuscript preparation. The mouse monoclonal anti- NEUROG3 antibody developed by Dr Ole D Madsen was obtained from the Developmental Studies Hybridoma Bank developed under the auspices of the NICHD and maintained by the University of Iowa, Department of Biological Sciences, Iowa City, IA 52242, USA.

\section{References}

Agarwal SK, Guru SC, Heppner C, Erdos MR, Collins RM, Park SY, Saggar S, Chandrasekharappa SC, Collins FS, Spiegel AM et al. 1999 Menin interacts with the AP1 transcription factor JunD and represses JunDactivated transcription. Cell 96 143-152.

Ahlgren U, Jonsson J \& Edlund H 1996 The morphogenesis of the pancreatic mesenchyme is uncoupled from that of the pancreatic epithelium in IPF1/PDX1-deficient mice. Development 122 1409-1416.

Apelqvist A, Li H, Sommer L, Beatus P, Anderson DJ, Honjo T, Hrabe de Angelis M, Lendahl U \& Edlund H 1999 Notch signalling controls pancreatic cell differentiation. Nature 400 877-881.

Attali M, Stetsyuk V, Basmaciogullari A, Aiello V, Zanta-Boussif MA, Duvillie B \& Scharfmann R 2007 Control of $\beta$-cell differentiation by the pancreatic mesenchyme. Diabetes 56 1248-1258.

Bertolino P, Radovanovic I, Casse H, Aguzzi A, Wang ZQ \& Zhang CX $2003 a$ Genetic ablation of the tumor suppressor menin causes lethality at mid-gestation with defects in multiple organs. Mechanisms of Development $120549-560$. 
Bertolino P, Tong WM, Galendo D, Wang ZQ \& Zhang CX 2003 b Heterozygous Men1 mutant mice develop a range of endocrine tumors mimicking multiple endocrine neoplasia type 1. Molecular Endocrinology 17 1880-1892.

Bertolino P, Tong WM, Herrera PL, Casse H, Zhang CX \& Wang ZQ $2003 c$ Pancreatic $\beta$-cell-specific ablation of the multiple endocrine neoplasia type 1 (MEN1) gene causes full penetrance of insulinoma development in mice. Cancer Research 63 4836-4841.

Bhushan A, Itoh N, Kato S, Thiery JP, Czernichow P, Bellusci S \& Scharfmann R 2001 Fgf10 is essential for maintaining the proliferative capacity of epithelial progenitor cells during early pancreatic organogenesis. Development 128 5109-5117.

Biondi CA, Gartside MG, Waring P, Loffler KA, Stark MS, Magnuson MA, Kay GF \& Hayward NK 2004 Conditional inactivation of the MEN1 gene leads to pancreatic and pituitary tumorigenesis but does not affect normal development of these tissues. Molecular and Cellular Biology 24 3125-3131.

Cano DA, Murcia NS, Pazour GJ \& Hebrok M 2004 Orpk mouse model of polycystic kidney disease reveals essential role of primary cilia in pancreatic tissue organization. Development 131 3457-3467.

Crabtree JS, Scacheri PC, Ward JM, McNally SR, Swain GP, Montagna C, Hager JH, Hanahan D, Edlund H, Magnuson MA et al. 2003 Of mice and MEN1: insulinomas in a conditional mouse knockout. Molecular and Cellular Biology 23 6075-6085.

Duvillie B, Attali M, Aiello V, Quemeneur E \& Scharfmann R 2003 Labelretaining cells in the rat pancreas: location and differentiation potential in vitro. Diabetes 52 2035-2042.

Duvillie B, Attali M, Bounacer A, Ravassard P, Basmaciogullari A \& Scharfmann R 2006 The mesenchyme controls the timing of pancreatic beta-cell differentiation. Diabetes 55 582-589.

Edlund H 2002 Pancreatic organogenesis-developmental mechanisms and implications for therapy. Nature Reviews. Genetics 3 524-532.

Gradwohl G, Dierich A, LeMeur M \& Guillemot F 2000 Neurogenin3 is required for the development of the four endocrine cell lineages of the pancreas. PNAS 97 1607-1611.

Guz Y, Montminy MR, Stein R, Leonard J, Gamer LW, Wright CV \& Teitelman G 1995 Expression of murine STF-1, a putative insulin gene transcription factor, in beta cells of pancreas, duodenal epithelium and pancreatic exocrine and endocrine progenitors during ontogeny. Development 121 11-18.

Heiser PW, Lau J, Taketo MM, Herrera PL \& Hebrok M 2006 Stabilization of beta-catenin impacts pancreas growth. Development 133 2023-2032.

Heppner C, Bilimoria KY, Agarwal SK, Kester M, Whitty LJ, Guru SC, Chandrasekharappa SC, Collins FS, Spiegel AM, Marx SJ et al. 2001 The tumor suppressor protein menin interacts with NF- $\mathrm{KB}$ proteins and inhibits NF- $\mathrm{BB}-$ mediated transactivation. Oncogene 20 4917-4925.

Herrera PL 2000 Adult insulin- and glucagon-producing cells differentiate from two independent cell lineages. Development 127 2317-2322.

Hughes CM, Rozenblatt-Rosen O, Milne TA, Copeland TD, Levine SS, Lee JC, Hayes DN, Shanmugam KS, Bhattacharjee A, Biondi CA et al. 2004 Menin associates with a trithorax family histone methyltransferase complex and with the hoxc8 locus. Molecular Cell 13 587-597.

Jacquemin P, Durviaux SM, Jensen J, Godfraind C, Gradwohl G, Guillemot F, Madsen OD, Carmeliet P, Dewerchin M, Collen D et al. 2000

Transcription factor hepatocyte nuclear factor 6 regulates pancreatic endocrine cell differentiation and controls expression of the proendocrine gene ngn3. Molecular and Cellular Biology 20 4445-4454.

Jensen J, Pedersen EE, Galante P, Hald J, Heller RS, Ishibashi M, Kageyama R, Guillemot F, Serup P \& Madsen OD 2000 Control of endodermal endocrine development by Hes-1. Nature Genetics 24 36-44.

Jonsson J, Carlsson L, Edlund T \& Edlund H 1994 Insulin-promoter-factor 1 is required for pancreas development in mice. Nature 371 606-609.

Kaji H, Canaff L, Lebrun JJ, Goltzman D \& Hendy GN 2001 Inactivation of menin, a Smad3-interacting protein, blocks transforming growth factor type beta signaling. PNAS 98 3837-3842.

Karnik SK, Chen H, McLean GW, Heit JJ, Gu X, Zhang AY, Fontaine M, Yen MH \& Kim SK 2007 Menin controls growth of pancreatic beta-cells in pregnant mice and promotes gestational diabetes mellitus. Science $\mathbf{3 1 8}$ 806-809.
Kim H, Lee JE, Cho EJ, Liu JO \& Youn HD 2003 Menin, a tumor suppressor, represses JunD-mediated transcriptional activity by association with an mSin3A-histone deacetylase complex. Cancer Research 63 6135-6139.

Larsson C, Skogseid B, Oberg K, Nakamura Y \& Nordenskjold M 1988 Multiple endocrine neoplasia type 1 gene maps to chromosome 11 and is lost in insulinoma. Nature $33285-87$.

Lee JC, Smith SB, Watada H, Lin J, Scheel D, Wang J, Mirmira RG \& German MS 2001 Regulation of the pancreatic pro-endocrine gene neurogenin3. Diabetes $\mathbf{5 0}$ 928-936.

Lin SY \& Elledge SJ 2003 Multiple tumor suppressor pathways negatively regulate telomerase. Cell 113 881-889.

MacPherson D, Sage J, Kim T, Ho D, McLaughlin ME \& Jacks T 2004 Cell type-specific effects of $\mathrm{Rb}$ deletion in the murine retina. Genes and Development 18 1681-1694.

Milne TA, Hughes CM, Lloyd R, Yang Z, Rozenblatt-Rosen O, Dou Y, Schnepp RW, Krankel C, Livolsi VA, Gibbs D et al. 2005 Menin and MLL cooperatively regulate expression of cyclin-dependent kinase inhibitors. PNAS 102 749-754.

Namihira H, Sato M, Murao K, Cao WM, Matsubara S, Imachi H, Niimi M, Dobashi H, Wong NC \& Ishida T 2002 The multiple endocrine neoplasia type 1 gene product, menin, inhibits the human prolactin promoter activity. Journal of Molecular Endocrinology 29 297-304.

Pierreux CE, Poll AV, Kemp CR, Clotman F, Maestro MA, Cordi S, Ferrer J, Leyns L, Rousseau GG \& Lemaigre FP 2006 The transcription factor hepatocyte nuclear factor- 6 controls the development of pancreatic ducts in the mouse. Gastroenterology 130 532-541.

Ravassard P, Chatail F, Mallet J \& Icard-Liepkalns C 1997 Relax, a novel rat bHLH transcriptional regulator transiently expressed in the ventricular proliferating zone of the developing central nervous system. Journal of Neuroscience Research 48 146-158.

Sayo Y, Murao K, Imachi H, Cao WM, Sato M, Dobashi H, Wong NC \& Ishida T 2002 The multiple endocrine neoplasia type 1 gene product, menin, inhibits insulin production in rat insulinoma cells. Endocrinology 143 $2437-2440$.

Smart NG, Apelqvist AA, Gu X, Harmon EB, Topper JN, MacDonald RJ \& Kim SK 2006 Conditional expression of Smad7 in pancreatic beta cells disrupts TGF- $\beta$ signaling and induces reversible diabetes mellitus. PLoS Biology 4 e39.

Sowa H, Kaji H, Canaff L, Hendy GN, Tsukamoto T, Yamaguchi T, Miyazono K, Sugimoto T \& Chihara K 2003 Inactivation of menin, the product of the multiple endocrine neoplasia type 1 gene, inhibits the commitment of multipotential mesenchymal stem cells into the osteoblast lineage. Journal of Biological Chemistry 278 21058-21069.

Sowa H, Kaji H, Kitazawa R, Kitazawa S, Tsukamoto T, Yano S, Tsukada T, Canaff L, Hendy GN, Sugimoto Tet al. 2004 Menin inactivation leads to loss of transforming growth factor beta inhibition of parathyroid cell proliferation and parathyroid hormone secretion. Cancer Research 64 2222-2228.

Stoffers DA, Ferrer J, Clarke WL \& Habener JF 1997 Early-onset type-II diabetes mellitus (MODY4) linked to IPF1. Nature Genetics 17 138-139.

Thakker RV 1998 Multiple endocrine neoplasia - syndromes of the twentieth century. Journal of Clinical Endocrinology and Metabolism 83 2617-2620.

Wilson ME, Scheel D \& German MS 2003 Gene expression cascades in pancreatic development. Mechanisms of Development 120 65-80.

Yokoyama A, Wang Z, Wysocka J, Sanyal M, Aufiero DJ, Kitabayashi I, Herr W \& Cleary ML 2004 Leukemia proto-oncoprotein MLL forms a SET1like histone methyltransferase complex with menin to regulate Hox gene expression. Molecular and Cellular Biology 24 5639-5649.

Yokoyama A, Somervaille TC, Smith KS, Rozenblatt-Rosen O, Meyerson M \& Cleary ML 2005 The menin tumor suppressor protein is an essential oncogenic cofactor for MLL-associated leukemogenesis. Cell 123 207-218.

Received in final form 28 August 2008

Accepted 1 September 2008

Made available online as an Accepted Preprint 3 September 2008 